\title{
PERANCANGAN SISTEM INFORMASI DATA ALUMNI FAKULTAS TEKNIK UNSRAT BERBASIS WEB
}

\author{
Ivan Arifard Watung, Alicia A. E. Sinsuw, ST.,MT, Sary D. E. Paturusi, ST.,M.Eng, Xaverius B. N. Najoan, ST.,MT \\ Jurusan Teknik Elektro-FT, UNSRAT, Manado-95115, Email: ivan.arifhard@gmail.com
}

\begin{abstract}
Information technology has become the primary choice in creating an information system that can provide accurate and precise information. Backround of alumni data information system that is still manual data processing. The purpose of this system is to design a webbased information system.

System design using the waterfall method comprising steps Information System Engineering, Requirements Analysis, Design, Coding, Testing, and Maintenance. Modeling using Flowmap or Flowchart, Context Diagram and Data Flow Diagrams.

Of this final project has designed an information system engineering faculty alumni data unsrat web based.
\end{abstract}

\section{Keywords: Information System Alumni, Alumni Data, Waterfall}

\begin{abstract}
Abstrak - Teknologi Informasi sudah menjadi pilihan utama dalam menciptakan suatu sistem informasi yang dapat memberikan informasi secara akurat dan tepat. Latar belakang dari sistem informasi data alumni yaitu pengolahan data masih manual. Adapun tujuan dari sistem ini yaitu untuk merancang suatu sistem informasi berbasis web.

Perancangan sistem menggunakan metode waterfall yang terdiri dari tahapan System Information Engineering, Requirements Analysis, Design, Coding, Testing, dan Maintenance. Pemodelan menggunakan Flowmap atau Flowchart, Diagram Konteks dan Data Flow Diagram. Dari pembuatan tugas akhir ini telah dirancang suatu sistem informasi data alumni fakultas teknik unsrat berbasis web.
\end{abstract}

Kata kunci : Sistem Informasi Alumni, Data Alumni, Waterfall

\section{PENDAHULUAN}

Perkembangan teknologi informasi di seluruh dunia telah membuat hidup manusia menjadi semakin lebih mudah. Terutama sejak diciptakannya jaringan internet, komunikasi menjadi semakin tidak terbatas.
Penerapan sistem informasi menjadi begitu penting untuk menunjang kegiatan kerja. Dengan perkembangan teknologi informasi kita dapat membangun sebuah sistem informasi yang bertujuan untuk membantu meningkatkan pekerjaan lebih mudah untuk mengakses data.

Data alumni merupakan salah satu contoh dari suatu sistem informasi yang dirancang untuk dapat membantu pekerjaan dari suatu instansi atau perusahan baik dalam mengolah data sampai memberikan data secara lengkap lewat tersedianya layanan informasi berbasis web.

Namun demikian, sejauh ini belum ada penerapan sistem informasi pengolahan data alumni berbasis web di fakultas teknik unsrat yang tentunya dapat membantu pekerjaan lebih mudah dalam mengolah, memberikan dan menampilkan data.

Sehubungan dengan hal ini, untuk lebih mempermudah memperoleh informasi dari data alumni Fakultas Teknik UNSRAT. Diperlukan suatu sistem informasi yang dapat menginformasikan data secara akurat dari para alumni yang ada. Guna mendapatkan informasi yang akurat dan mudah dalam pengaksesan datanya, maka informasi dapat dirangkum dalam sebuah sistem informasi berbasis web dan perlu juga dibangun sebuah sistem informasi yang tentunya dapat mempermudah proses akses data tersebut pada database. Lewat penggunaan metode waterfall dan juga tahapan-tahapan diagram konteks bahkan data flow diagram dapat mempermudah untuk merancang aplikasi yang dirancang ini.

Berdasarkan paparan diatas maka penulis berkeinginan untuk membuat suatu sistem informasi berbasis web dengan mengangkat judul "Perancangan Sistem Informasi Data Alumni Fakultas Teknik Unsrat Berbasis Web”

\section{LANDASAN TEORI}

\section{A. Sistem Informasi}

Tidak semua data dapat diolah dan digunakan sebagai bahan pertimbangan keputusan dalam perusahaan. Oleh karena itu dibutuhkan suatu sistem yang dapat mengolah data. Sistem itu harus dirancang sedemikian rupa agar dapat menntukan validitas data yang berasal dari berbagai sumber

Sistem informasi dapat didefinisikan sebagai kumpulan elemen yang saling berhubungan satu sama lain yang membentuk satu kesatuan untuk mengintegrasikan data memproses dan menyimpan serta mendistribusikan informasi. Dengan kata lain SI merupakan kesatuan elemen-elemen yang saling berinteraksi secara sistematis dan teratur untuk menciptakan dan membentuk aliran informasi yang akan 
mendukung pembuatan keputusan dan melakukan kontrol terhadap jalannya perusahaan.

Menurut (McLeod, 2004) informasi adalah data yang diolah menjadi bentuk lebih berguna dan lebih berarti bagi yang menerimanya. Informasi merupakan data yang telah diproses sedemikian rupa sehingga meningkatkan pengetahuan seseorang yang menggunakan. Sistem apapun tanpa ada informasi tidak akan berguna, karena sistem tersebut akan mengalami kemacetan dan akhirnya berhenti.

Informasi dapat berupa data mentah, data tersusun, kapasitas sebuah saluran informasi, dan sebagainya.

\section{B. Basis Data}

Basis data merupakan komponen terpenting dalam pembangunan SI, karena menjadi tempat untuk menampung dan mengorganisasikan seluruh data yang ada dalam sistem, sehingga dapat dieksplorasi untuk menyusun informasiinformasi dalam berbagai bentuk. Basis data merupakan himpunan kelompok data yang saling berkaitan.

Dengan basis data, pengguna dapat menyimpan data secara terorganisasi. Setelah data disimpan, informasi harus mudah diambil.

Prinsip utama basis data adalah pengaturan data dengan tujuan utama fleksibilitas dan kecepatan dalam pengambilan data kembali.

Bahasa basis data (database language) adalah suatu cara untuk berinteraksi atau berkomunikasi antara pemakai dengan basis data yang diatur dalam bahasa khusus yang ditetapkan oleh perusahaan. Database language dipilah menjadi 3 yaitu;

1. Data Definition Language (DDL),

2. Data Manipulation Language (DML), dan

3. Data Control Language (DCL).

DDL merupakan singkatan dari Data Definition Language yang juga bagian dari strutured query language $(S Q L)$. DDL berfungsi lebih ke dalam memanipulasi struktur dari database. DDL digunakan untuk membuat tabel atau menghapus tabel, membuat key atau indeks, membuat relasi antartabel.

Structured Query Language (SQL) adalah sekumpulan sintaks-sintaks atau statement untuk mengakses data dalam database, tetapi SQL sendiri juga bisa digunakan untuk melakukan proses insert, update atau delete ke dalam suatu database. Sintaks-sintaks ini yang disebut dengan Data Manipulation Language (DML) yang merupakan bagian dari SQL.

Data Control Language (DCL) merupakan kelompok perintah yang berisi untuk mengendalikan pangaksesan data DCL digunakan untuk menangani masalah keamanan dalam database server

\section{PHP}

PHP atau kependekan dari Hypertext Preprocessor adalah salah satu bahasa pemrograman open source yang sangat cocok atau dikhususkan untuk pengembangan Web dan dapat di tanamkan pada sebuah skrip HTML. Bahasa PHP dapat dikatakan menggambarkan beberapa bahasa pemrograman seperti C, Java, dan Perl serta mudah untuk dipelajari.
Sistem kerja dari PHP diawali dengan permintaan yang beasal dari halaman website oleh browser. Berdasarkan URL atau alamat website dalam jaringan internet, browser akan menemukan sebuah alamat dari webserver, mengidentifikasi halaman yang dikehendaki, dan menyampaikan segala informasi yang dibutuhkan oleh webserver.

Selanjutnya webserver akan mencarikan berkas yang diminta dan menampilkan isinya di browser. Browser yang mendapatkan isinya segera menerjemahkan kode HTML dan menampilkannya. Lalu bagaimana apabila yang dipanggil oleh user adalah halaman yang mengandung script PHP ? Pada prinsipnya sama dengan memanggil kode HTML, namun pada saat permintaan dikirim ke web-server, web-server akan memeriksa tipe file yang diminta user. Jika tipe file yang diminta adalah pHP, maka akan memeriksa isi script dari halaman PHP tersebut.

\section{MySQL}

MySQL adalah sebuah perangkat lunak sistem manajemen basis data SQL (bahasa Inggris: database management system) atau DBMS yang multithread, multiuser, dengan sekitar 6 juta instalasi di seluruh dunia. MySQL AB membuat MySQL tersedia sebagai perangkat lunak gratis dibawah lisensi GNU General Public License (GPL), tetapi mereka juga menjual dibawah lisensi komersial untuk kasuskasus dimana penggunaannya tidak cocok dengan penggunaan GPL.

MySQL adalah Relational Database Management System (RDBMS) yang didistribusikan secara gratis dibawah lisensi GPL (General Public License). Dimana setiap orang bebas untuk menggunakan MySQL, namun tidak boleh dijadikan produk turunan yang bersifat komersial.

MySQL sebenarnya merupakan turunan salah satu konsep utama dalam database sejak lama, yaitu SQL (Structured Query Language). SQL adalah sebuah konsep pengoperasian database, terutama untuk pemilihan atau seleksi dan pemasukan data, yang memungkinkan pengoperasian data dikerjakan dengan mudah secara otomatis.

Keandalan suatu sistem database (DBMS) dapat diketahui dari cara kerja optimizer-nya dalam melakukan proses perintah-perintah SQL, yang dibuat oleh user maupun program-program aplikasinya.

Sebagai database server, MySQL dapat dikatakan lebih unggul dibandingkan database server lainnya dalam query data. Hal ini terbukti untuk query yang dilakukan oleh single user, kecepatan query MySQL bisa sepuluh kali lebih cepat dari PostgreSQL dan lima kali lebih cepat dibandingkan Interbase.

MySQL memiliki beberapa keistimewaan, antara lain :

1. Portabilitas. MySQL dapat berjalan stabil pada berbagai sistem operasi seperti Windows, Linux, FreeBSD, Mac Os X Server, Solaris, Amiga, dan masih banyak lagi.

2. Open Source.MySQL didistribusikan secara open source, dibawah lisensi GPL sehingga dapat digunakan secara cuma-cuma.

3. 'Multiuser'. MySQL dapat digunakan oleh beberapa user dalam waktu yang bersamaan tanpa mengalami masalah atau konflik. 
4. 'Performance tuning'. MySQL memiliki kecepatan yang menakjubkan dalam menangani query sederhana, dengan kata lain dapat memproses lebih banyak SQL per satuan waktu.

5. Jenis Kolom. MySQL memiliki tipe kolom yang sangat kompleks, seperti signed / unsigned integer, float, double, char, text, date, timestamp, dan lainlain.

6. Perintah dan Fungsi. MySQL memiliki operator dan fungsi secara penuh yang mendukung perintah Select dan Where dalam perintah (query).

7. Keamanan. MySQL memiliki beberapa lapisan sekuritas seperti level subnetmask, nama host, dan izin akses user dengan sistem perizinan yang mendetail serta sandi terenkripsi.

8. Skalabilitas dan Pembatasan. MySQL mampu menangani basis data dalam skala besar, dengan jumlah rekaman (records) lebih dari 50 juta dan 60 ribu tabel serta 5 milyar baris. Selain itu batas indeks yang dapat ditampung mencapai 32 indeks pada tiap tabelnya.

9. Konektivitas. MySQL dapat melakukan koneksi dengan klien menggunakan protokol TCP/IP, Unix soket (UNIX), atau Named Pipes (NT).

10. Lokalisasi. MySQL dapat mendeteksi pesan kesalahan pada klien dengan menggunakan lebih dari dua puluh bahasa. Meski pun demikian, bahasa Indonesia belum termasuk di dalamnya.

11. Antar Muka. MySQL memiliki interface (antar muka) terhadap berbagai aplikasi dan bahasa pemrograman dengan menggunakan fungsi API (Application Programming Interface).

12. Klien dan Peralatan. MySQL dilengkapi dengan berbagai peralatan (tool)yang dapat digunakan untuk administrasi basis data, dan pada setiap peralatan yang ada disertakan petunjuk online.

13. Struktur tabel. MySQL memiliki struktur tabel yang lebih fleksibel dalam menangani ALTER TABLE, dibandingkan basis data lainnya semacam PostgreSQL ataupun Oracle.

\section{E. Model Proses Waterfall}

Salah satu metode perancangan menurut Pressman (1997) yang dapat digunakan adalah Metode Waterfall. Nama model ini sebenarnya adalah "Linear Sequential Model". Model ini sering disebut dengan "classic life cycle" atau model waterfall.

Model ini adalah model yang muncul pertama kali yaitu sekitar tahun 1970 sehingga sering dianggap kuno, tetapi merupakan model yang paling banyak dipakai didalam Software Engineering (SE).

Model ini melakukan pendekatan secara sistematis dan urut mulai dari level kebutuhan sistem lalu menuju ke tahap analisis, desain, coding, testing / verification, dan maintenance. Disebut dengan waterfall karena tahap demi tahap yang dilalui harus menunggu selesainya tahap sebelumnya dan berjalan berurutan.

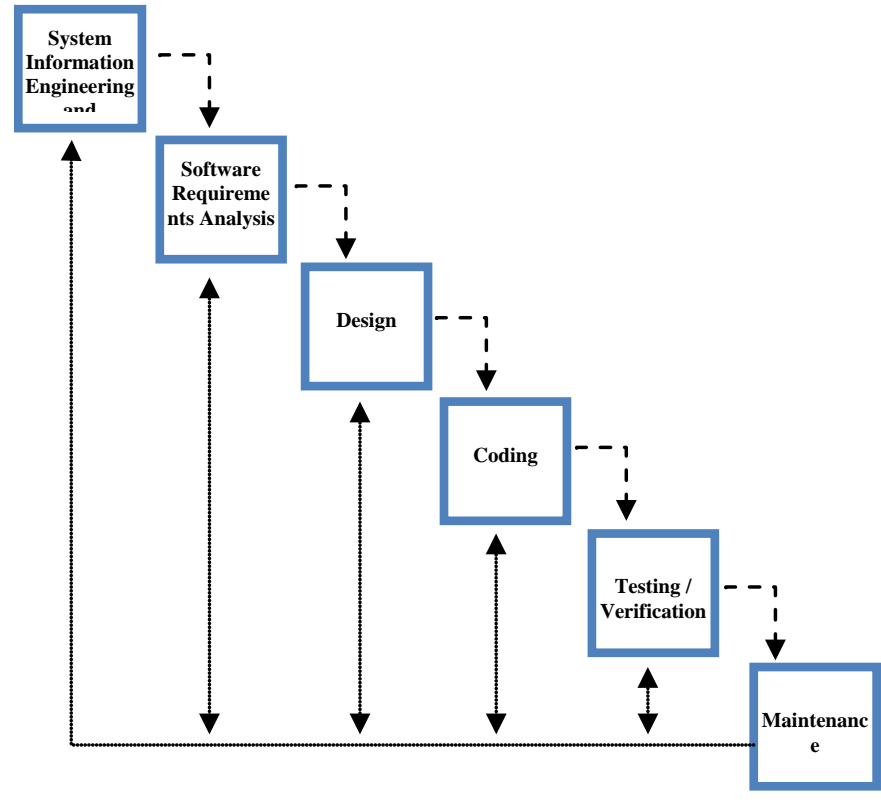

Gambar Model Waterfall

Gambar 2.2 di atas adallah tahapan dari model waterfall. Pressman memecah model ini menjadi 6 tahapan meskipun secara garis besar sama dengan tahapan-tahapan model waterfall pada umumnya. Berikut adalah penjelasan dari tahap-tahap yang dilakukan di dalam model ini menurut Pressman:

\section{System / Information Engineering and Modeling}

Permodelan ini diawali dengan mencari kebutuhan dari keseluruhan sistem yang akan diaplikasikan ke dalam bentuk software. Hal ini sangat penting, mengingat software harus dapat berinteraksi dengan elemen-elemen yang lain seperti hardware, database, dsb. Tahap ini sering disebut dengan Project Definition.

\section{Software Requirements Analysis}

Proses pencarian kebutuhan diintensifkan dan difokuskan pada software. Untuk mengetahui sifat dari program yang akan dibuat, maka para software engineer harus mengerti tentang domain informasi dari software, misalnya fungsi yang dibutuhkan, user interface, dsb.

\section{Design}

Proses ini digunakan untuk mengubah kebutuhankebutuhan diatas menjadi representasi ke dalam bentuk "blueprint" software sebelum coding dimulai. Desain harus dapat mengimplementasikan kebutuhan yang telah disebutkan pada tahap sebelumnya.

\section{Coding}

Untuk dapat dimengerti oleh mesin, dalam hal ini adalah komputer, maka desain tadi harus diubah bentuknya menjadi bentuk yang dapat dimengerti oleh mesin, yaitu ke dalam bahasa pemrograman melalui prose coding. Tahap ini merupakan implementasi dari tahap design yang secara teknis nantinya dikerjakan oleh programmer. 


\section{Testing / Verification}

Sesuatu yang dibuat haruslah diujicobakan. Demikian juga dengan software. Semua fungsi-fungsi software harus diujicobakan, agar software bebas dari error, dan hasilnya harus benar-benar sesuai dengan kebutuhan yang sudah didefinisikan sebelumnya.

\section{Maintenance}

Pemeliharaan suatu software diperlukan, termasuk di dalamnya adalah pengembangan, karena software yang dibuat tidak selamanya hanya seperti itu. Ketika dijalankan mungkin saja masih ada error kecil yang tidak ditemukan sebelumnya, atau ada penambahan fitur-fitur yang belum ada pada software tersebut. Pengembangan diperlukan ketika adanya perubahan dari eksternal seperti ketika ada pergantian sistem operasi, atau perangkat lainnya.

\section{METODE PENELITIAN}

\section{A. Metode Perancangan Sistem}

Metode Waterfall

Metode ini merupakan salah satu metode yang sering digunakan oleh penganalisa sistem pada umumnya. Inti dari metode waterfall adalah pengerjaan dari suatu sistem dilakukan secara berurutan atau secara linear. Jadi jika langkah ke-1 belum dikerjakan, maka langkah ke-2 tidak dapat dikerjakan, jadi harus mengikuti tahapan demi tahapan untuk bisa lanjut pada langkah selanjutnya.

Beberapa tahapan metode waterfall akan dijelaskan sesuai yang dilakukan dalam pembuatan aplikasi pada Tugas akhir ini :

1. System information engineering and modeling Sistem informasi teknik dan pemodelan ini, pada sistem ini penulis mencari kebutuhan dari keseluruhan sistem yang akan diaplikasikan ke dalam software.

2. Requirements analysis

Analisis kebutuhan, setelah mencari kebutuhan yang ada di sistem selanjutnya kebutuhan ini akan diintensifkan dan difokuskan pada pembuatan software dengan selanjutnya merancang interface.

3. Design

Setelah dirancang interface maka yang diperlukan yaitu atribut yang akan digunakan berupa struktur, arsitektur, algoritma, dan karakteristik yang dipakai untuk menjalankan sistem ini

4. Coding

Pada tahapan ini design yang telah dirancang akan diubah kedalam bahasa pemrograman atau menerjemahkan data yang dirancang ke dalam bahasa pemrograman agar nantinya dapat dimengerti oleh mesin computer.
5. Testing

Uji coba terhadap program yang dibuat, apabila error maka harus kembali ke tahapan coding untuk mencari kesalahan yang ada.

6. Maintenance

Pemeliharaan, pada tahapan ini perubahan dan penambahan program dilakukan sesuai dengan permintaan.

Diagram Konteks

Secara umum rancangan sistem dapat digambarkan pada diagram konteks di bawah ini:

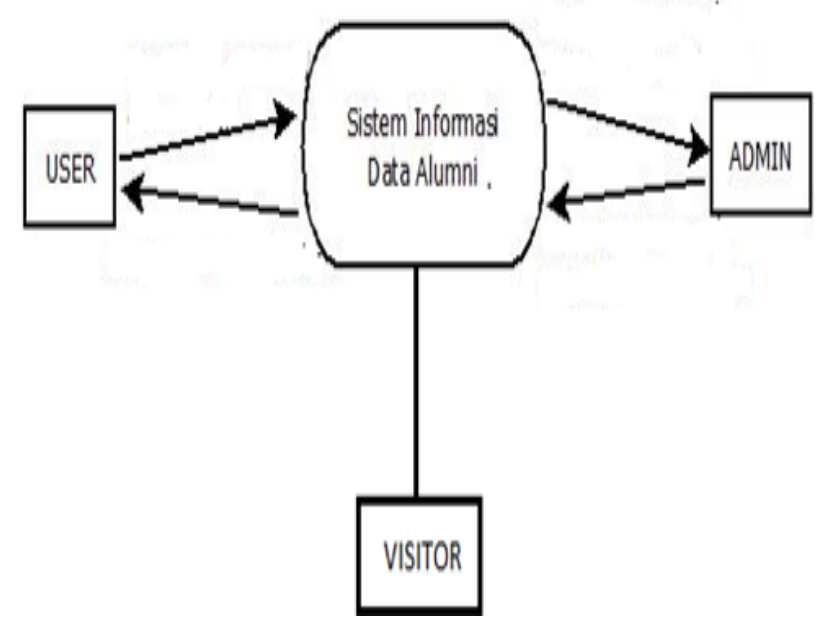

Gambar 3.1 Diagram Konteks

Gambar 3.1 menggambarkan hubungan antara sistem dengan lingkungan diluarnya yaitu User, Admin, dan Visitor. Penjelasan proses pada Gambar 3.1 dijabarkan sebagai berikut:

- Input Sistem

- User : Username, Password

Dalam sistem informasi ini user diberikan password untuk bisa masuk ke dalam sistem dengan adanya batasan yang diberikan, user sendiri hanya bisa melihat tanpa merubah data yang ada dalam sistem, user hanya bisa merubah dan menambahkan data pada profil pribadi yang telah disediakan.

- Admin : Username, Password

Dalam sistem informasi yang dirancang ini Admin diberikan kebebasan sepenuhnya untuk dapat mengolah data alumni yang telah ada, baik itu menambahkan data, mengedit data, dan menghapus data, bahkan juga memberikan informasi melalui data yang ada. Admin sendiri diberikan juga password untuk dapat masuk pada tampilan pengolahan data. 
- Visitor :

Dalam sistem informasi data alumni yang dirancang ini visitor atau pengunjung bisa masuk dan hanya bisa melihat tanpa menambahkan data.

- Output system

- Admin

Tampilan keseluruhan Sistem dan Tampilan Kelola Data

- User

Tampilan Keseluruhan Sistem dan Tampilan

- Visitor Carrerlog (profil pribadi)

Tampilan Keseluruhan Sistem

- Deskripsi Proses

Pada umumnya sistem ini akan menerima input dari entitas diluarnya yaitu user dan admin. Apabila admin mengakses sistem maka admin dapat melakukan pengolahan data sesuai dengan penjelasan di atas, begitu juga dengan user apabila status akses dilakukan oleh user maka proses yang dilakukan yaitu proses pengolahan data, dengan adanya beberapa batasan dalam sistem tersebut. Admin dan user sendiri diberikan password untuk dapat masuk ke dalam sistem yang di rancang ini. sedangkan visitor atau pengunjung hanya bisa mengunjungi tanpa melakukan pengolahan data

\section{Data Flow Diagram (DFD)}

1. DFD Level 0

Diagram level 0 merupakan dekomposisi dari diagram konteks, berikut adalah diagram level 0 dari sistem yang dirancang :

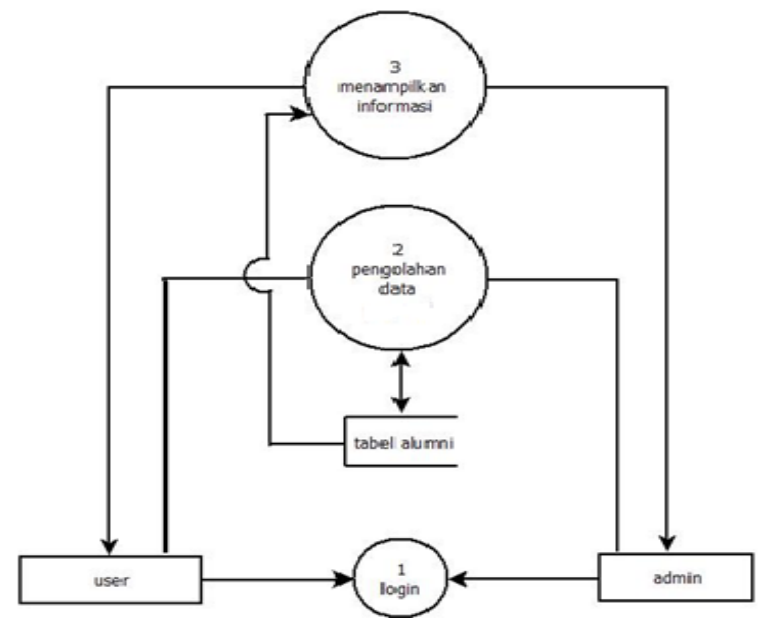

Gambar 3.2 Diagram Level 0

Penjelasan proses diagram diatas (Gambar 3.2) dijabarkan sebagai berikut:

a. Proses Login (1)

- Input : Username, Password.
User dan Admin terlebih dahulu harus memberikan password untuk masuk ke dalam sistem yang dirancang ini, apabila password sesuai maka dapat mengakses sistem ini jika password tidak sesuai akan kembali ke tampilan login.

- Output :

Tampilan keseluruhan sistem untuk menjalankan proses selanjutnya.

Admin dapat mengakses sepenuhnya sistem ini, sedangkan User akan diberikan

batasan untuk dapat masuk pada sistem selanjunya.

- Deskripsi proses

Untuk menjalankan program user dan admin harus melakukan proses login. Username dan password yang diinput akan diperiksa pada database. Apabila sesuai dapat dilanjutkan ke proses berikutnya.

b. Proses Pengolahan Data Alumni (2)

- Input :

- $\quad$ Status akses user dan admin

- Data Alumni

- Username, Password

- Output :

- Data Alumni

- Tampilan keseluruhan sistem

- Deskripsi proses

Proses ini akan aktif jika admin melakukan proses login. untuk pengolahan data selanjutnya. Begitu juga dengan user dengan dibatasinya beberapa tampilan

c. Proses Menampilkan Informasi

- Input :

- Username, Password

- Data Alumni

- Output :

- Data Alumni

- Tampilan keseluruhan sistem

- Deskripsi proses

Pada proses ini akan ditampilkan data dari Alumni yang ada di Fakultas Teknik Unsrat

2. DFD Level 1 Proses Login

DFD Level 1 proses login digambarkan sebagai berikut :

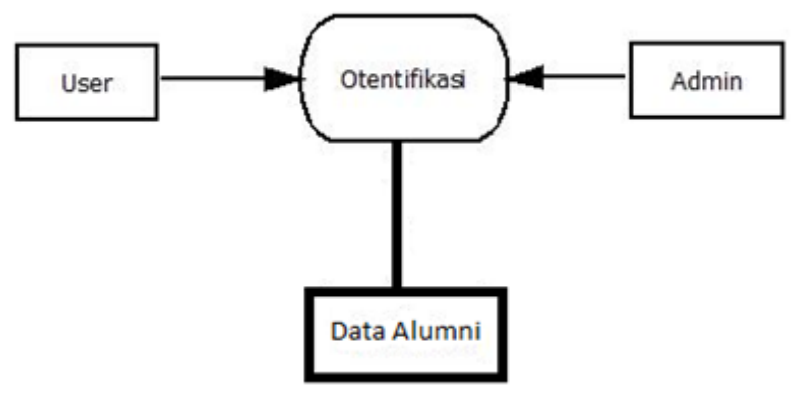

Gambar 3.3 DFD Level 1 Proses Login 
Penjelasan proses dari diagram di atas (Gambar 3.3) dijabarkan sebagai berikut :

a. Proses Otentifikasi (1.1)

- Input :

- $\quad$ Username, Password

- $\quad$ Status akses dari tabel Admin dan User

- Output :

- Tampilan keseluruhan sistem

- $\quad$ Status akses

- Deskripsi proses

Untuk menggunakan aplikasi user dan admin harus melakukan proses login dengan menggunakan akun yang dimiliki berupa username dan password. Setelah itu proses otentifikasi akan berjalan untuk melihat kecocokan data. Apabila username dan password terdapat dalam database maka proses login akan dilanjutkan.

3. DFD Level 1 Proses Tambah Data Alumni

DFD Level 1 proses Tambah Data Alumni digambarkan sebagai berikut :

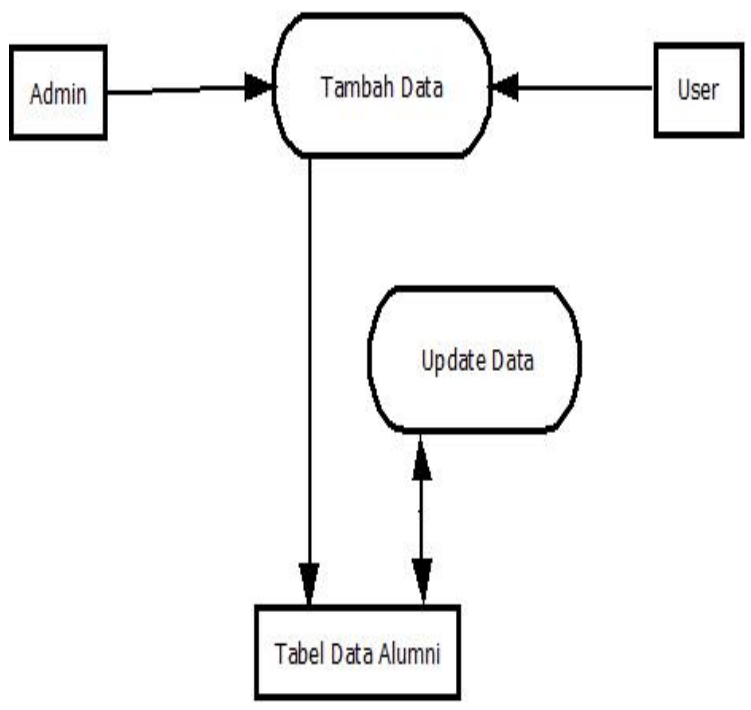

Gambar 3.4 DFD Level 1 Proses Pengolahan Data Alumni

- Input :

- $\quad$ Username, Password

- Data Alumni

- Output :

- Tampilan keseluruhan system

- Tampilan tabel data alumni

- Deskripsi proses

Dalam tahap ini admin harus melakukan proses pengisian data Alumni. Sedangkan User sendiri pada tahap ini hanya boleh mengisi data pribadi sendiri yang tentunya akan masuk pada sistem ini dengan proses login.

\section{B. Perancangan Tabel Database}

Sistem yang dirancang akan diintegrasikan dengan database sebagai penyimpanan data. Dalam database yang akan digunakan ini terdiri dari 4 tabel yaitu tabel tb_alumni, tabel user, tabel tb_karir dan tabel tb_skill. Berikut adalah rancangan database dari sistem

a. Tabel tb_alumni

Tabel ini berfungsi untuk menyimpan identitas dari alumni yang ada di Fakultas Teknik Unsrat.

b. Tabel user

Tabel ini berfungsi untuk menyimpan akun dari user dan admin yang nantinya akan menggunakan aplikasi yang dirancang ini, tabel ini akan digunakan pada proses login

c. Tabel tb_karir

Tabel ini berfungsi untuk menyimpan data dari alumni yang telah menambahkan data pribadi sendiri

d. Tabel tb_skill

Tabel ini berfungsi untuk menyimpan dara dari alumni yang telah menambahkan data pribadi sendiri

C. Proses Kerja

1.Proses kerja yang berjalan dibagian kemahasiswaan Fatek Unsrat

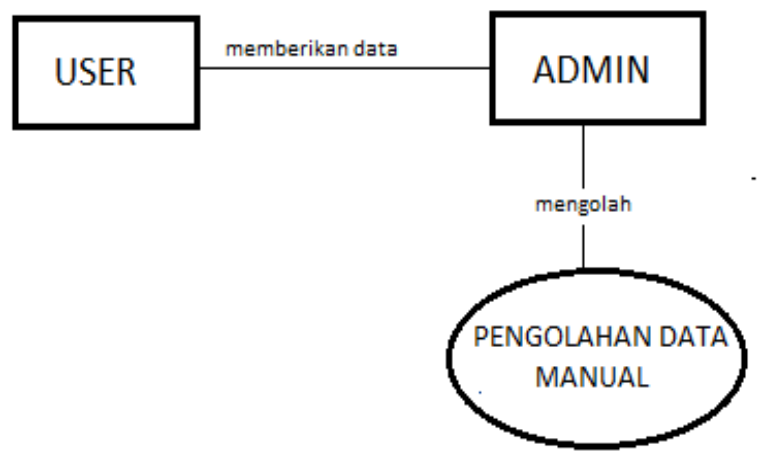

Pada gambar dijelaskan bagaimana sistem yang sedang berjalan, dimana user sendiri memasukkan/memberikan data kepada admin, kemudian selanjutnya admin mengolah data tersebut menjadi suatu sistem informasi.

2.Proses kerja yang akan dibuat pada tugas akhir ini

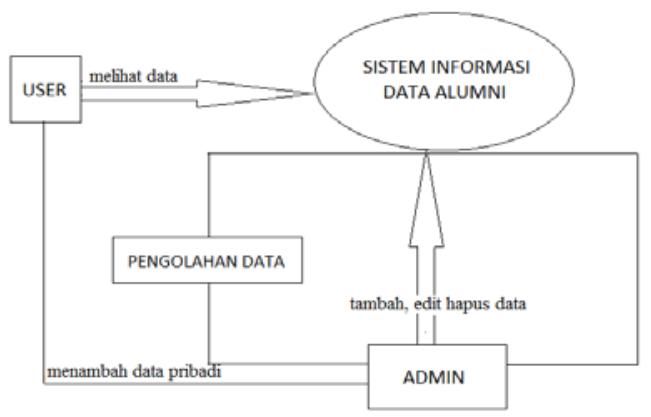


Pada gambar ini dijelaskan bagaimana user dan admin menjadi aktor utama dalam sistem ini, user sendiri bisa melihat data yang ada pada sistem, dan bisa menambah data pribadi kepada admin untuk selanjutnya dikelola untuk menjadi suatu sistem informasi. Sedangkan admin bisa sepenuhnya mengakses sistem ini lewat mengelolah data, menambah data, edit data, dan menghapus data juga.

\section{HASIL DAN PEMBAHASAN}

Pembuatan Aplikasi

Dalam tahap ini dilakukan proses coding sebagai implementasi dari tahap design. Program dari aplikasi ini dirancang dengan menggunakan macromedia dreamweaver, langkah pertama yang harus dilakukan dalam pembuatan program ini adalah mrnambahkan database server yang disimpan dalam MySQL.

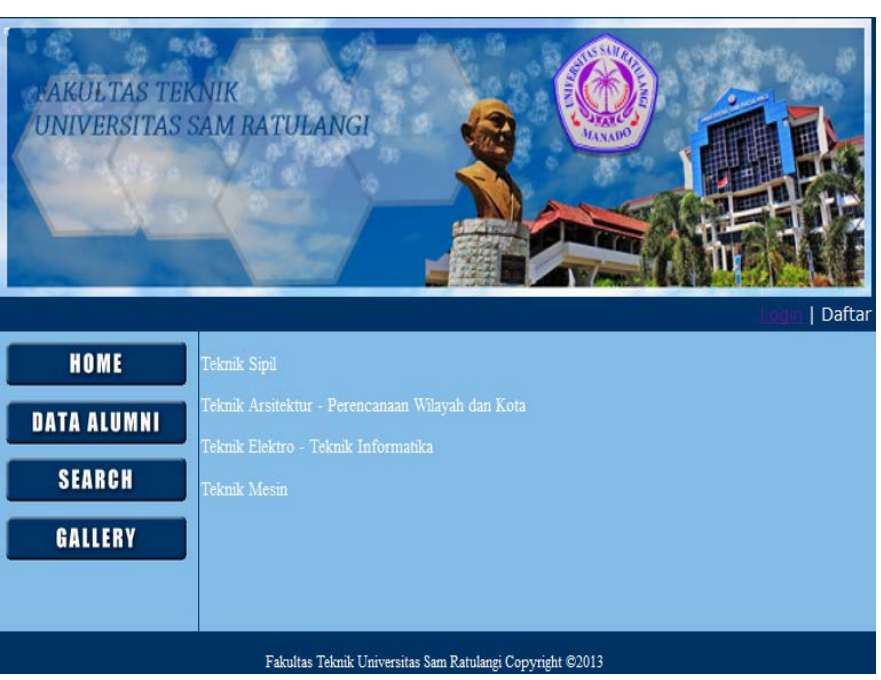

Gambar 4.1 Tampilan Awal
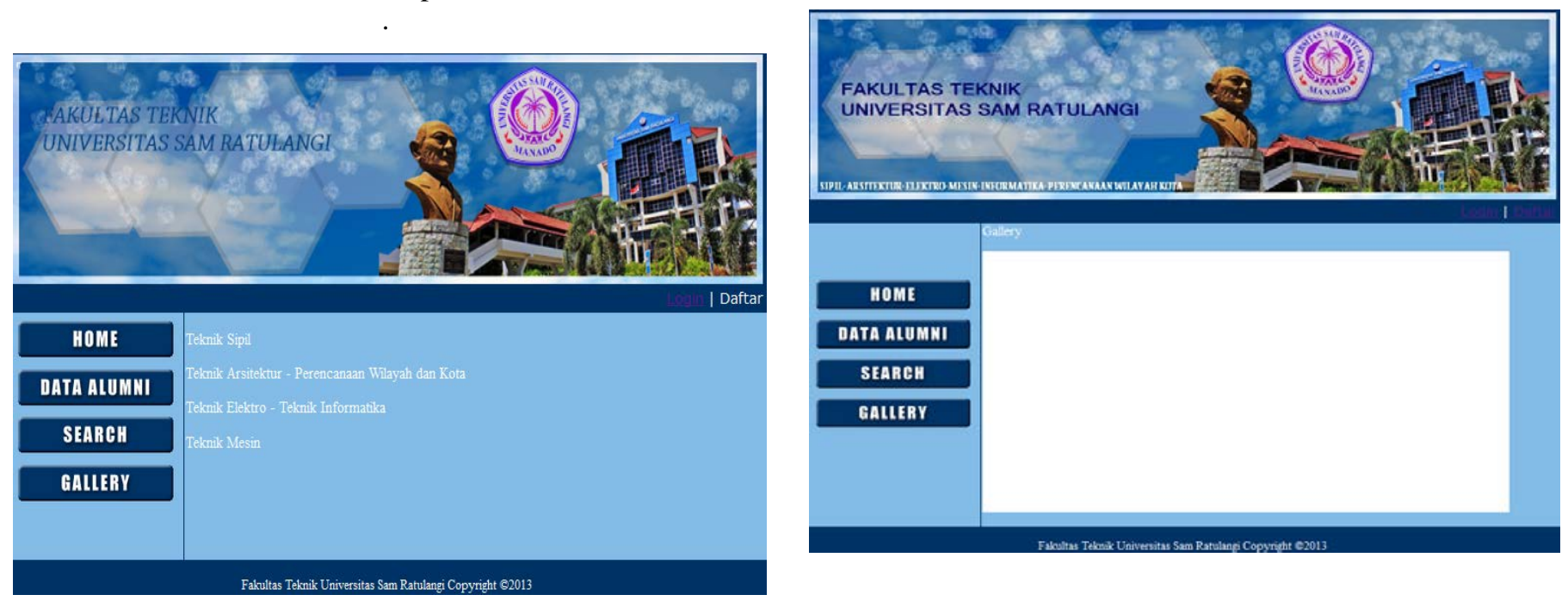

Gambar 4.2 Tampilan Home

Gambar 4.5 Tampilan Gallery

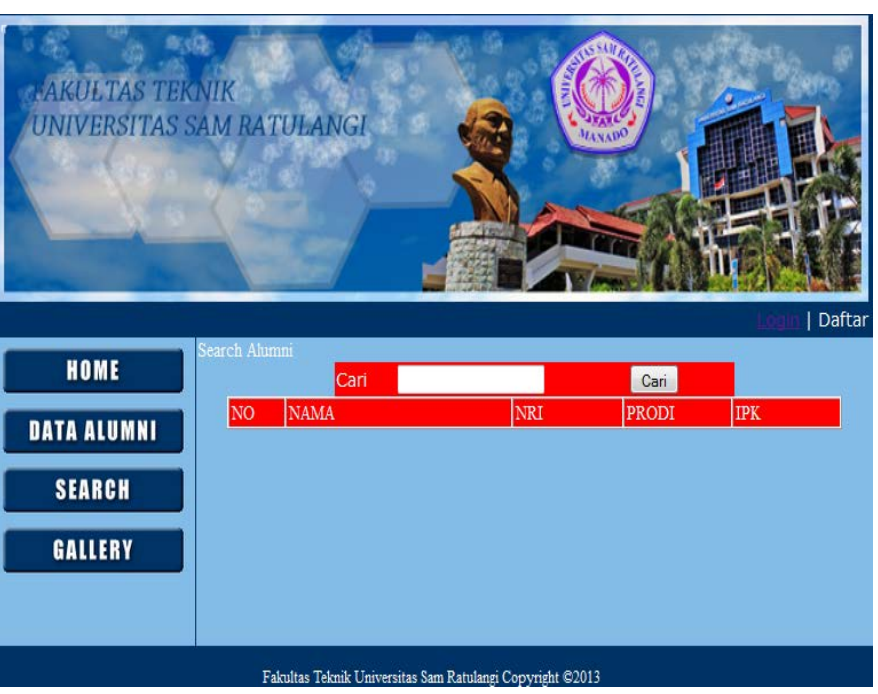

Gambar 4.4 Tampilan Search
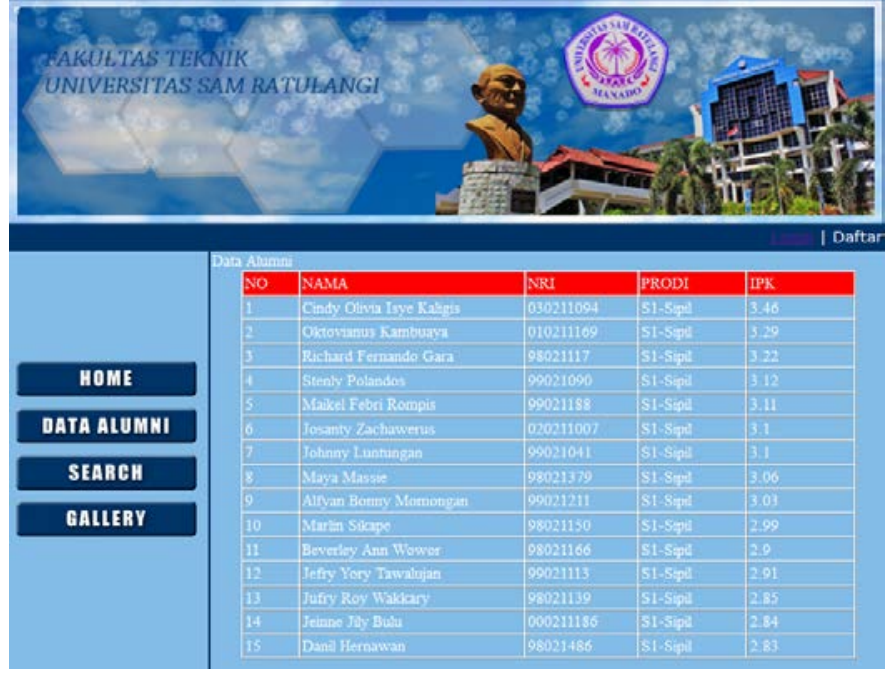

Gambar 4.3 Tampilan Data Alumni 


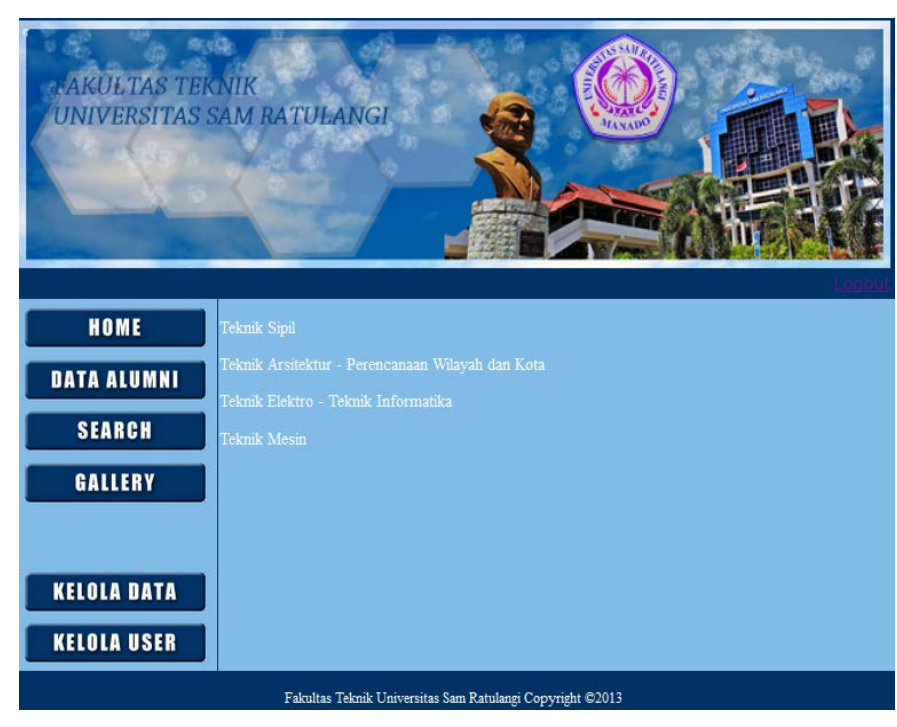

Gambar 4.6 Tampilan Awal Admin

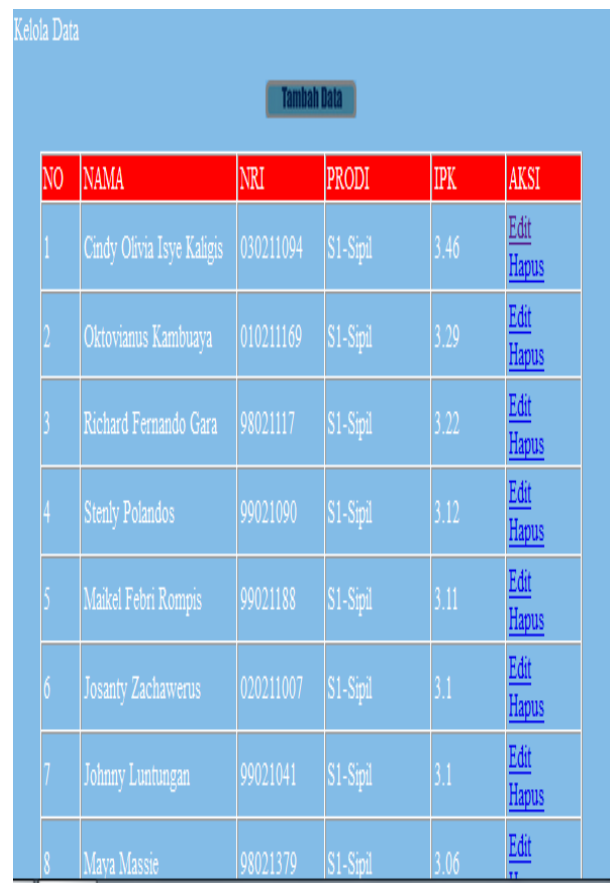

Gambar 4.7 Tampilan Kelola Data

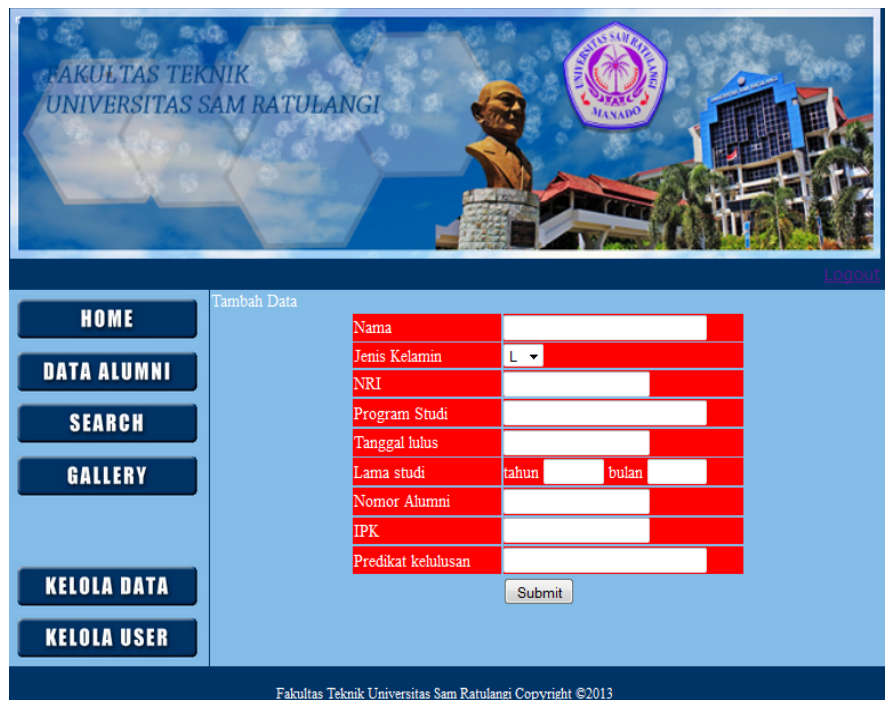

Gambar 4.8 Tampilan Tambah Data

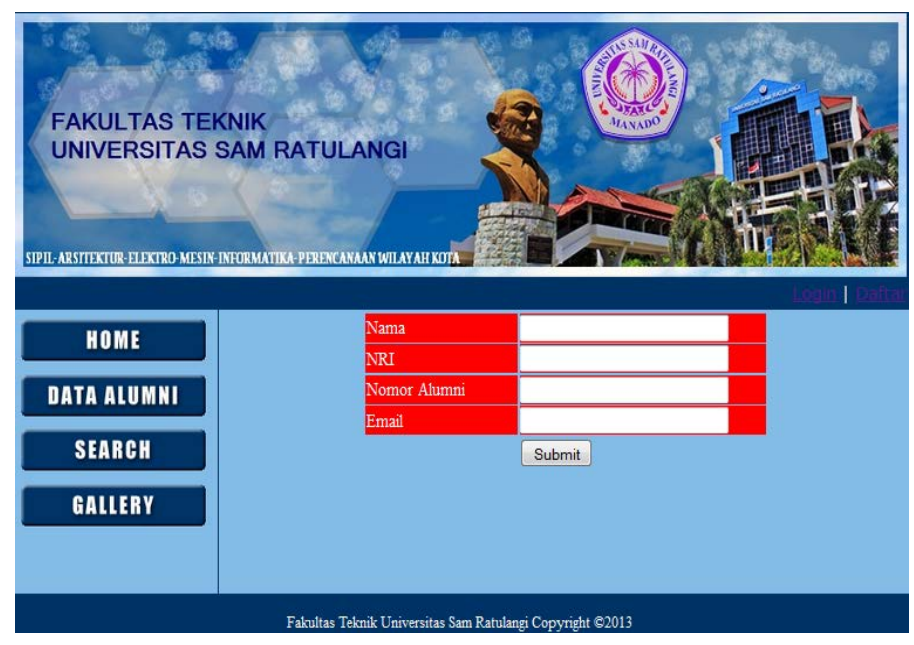

Gambar 4.9 Tampilan Daftar

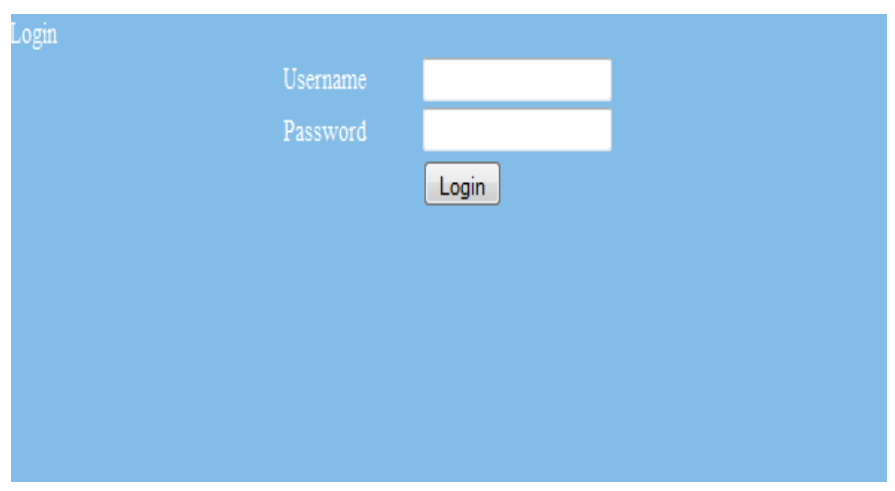

Gambar 4.10 Tampilan login 
Gambar 4.1 Tampilan Awal

Gambar ini merupakan tampilan awal atau pembuka dari halaman web data Alumni Fatek Unsrat. Pada tampilan ini terdapat 4 menu yang ada yaitu Home, Data Alumni, Search dan Gallery.

\section{Gambar 4.2 Tampilan Home}

Pada tampilan Home ini, web akan menampilkan halaman dengan mencantumkan informasi-informasi dan juga karakteristik dari Fakultas Teknik Unsrat. Halaman web ini akan terlihat ketika masuk pada menu Home.

\section{Gambar 4.3 Tampilan Data Alumni}

Pada tampilan ini, web akan menampilkan halaman data alumni dengan memberikan tampilan informasi mengenai alumni yang telah ada, alumni akan ditampilkan seluruh.

\section{Gambar 4.4 Tampilan Search}

Pada tampilan ini telah tersedia juga tampilan menu search yang bertujuan untuk mencari data alumni yang ada lewat pengisian nama dan nri untuk dapat mencari data yang diinginkan dan secara otomatis data yang dicari akan langsung ditampilkan.

\section{Gambar 4.5 Tampilan Gallery}

Pada web ini diberikan juga menu gallery yang akan menampilkan beberapa gambar dari fakultas teknik unsrat

\section{Gambar 4.6 Tampilan Awal Admin}

Halaman ini merupakan bagian dari tampilan awal hanya ditambahkan pada menu kelola data dan kelola user. Untuk dapat masuk ke halaman ini admin harus login apabila password sesuai maka akan muncul ke tampilan dibawah ini.

\section{Gambar 4.7 Tampilan Kelola Data}

Pada tampilan ini halaman kelola data telah ditambah dengan menu yang bisa edit dan hapus data. Dan bisa juga untuk menambah data,.

\section{Gambar 4.8 Tampilan Tambah Data}

Pada gambar ini halaman tambah data akan menampilkan menu pengisian data alumni yang ingin ditambahkan.

\section{Gambar 4.9 Tampilan Daftar}

Tampilan daftar ini ditujukan kepada alumni yang akan mendaftar untuk mendapatkan password masuk kedalam tampilan karirlog dan profil pribadi.

\section{Gambar 4.10 Tampilan Login}

Tampilan Login ini ditujukan kepada user yang ingin menambahkan data secara pribadi, dan juga admin yang akan mengolah data baik menghapus, menambah, dan mengedit data yang ada.

\section{Kesimpulan \\ V. Kesimpulan Dan Saran \\ Dari pembuatan tugas akhir ini telah dirancang suatu} Sistem Informasi Data Alumni Fakultas Teknik Unsrat Berbasis Web, dengan manfaat sebagai berikut:
1. Dengan tersedianya sistem informasi data alumni ini dapat memberikan kemudahan kepada admin dalam hal ini "bagian kemahasiswaan" untuk menginput data alumni.

2. Dapat memberikan informasi mengenai data-data alumni yang bisa dilihat lewat mengakses web yang telah dibuat lewat database yang ada.

3. Dapat membantu juga pegawai bagian kemahasiswaan yang ada untuk memiliki sebuah sistem informasi berbasis web.

Dengan menggunakan metode Waterfall, dapat membantu dalam proses pembuatan aplikasi sistem informasi data alumni fakultas teknik unsrat.

Saran

Beberapa saran yang berkaitan dengan pengembangan sistem ini:

1. Diperlukannya komputer yang mampu menjalankan dan mengimplementasikan sistem yang dirancang ini.

2. Diperlukannya orang yang bisa mengerti untuk dapat menjalankan sistem ini, khususnya dibagian kemahasiswaan.

\section{DAFTAR PUSTAKA}

Al-bahra Bin Ladjamudin. 2005. Analisis dan Desain Sistem Informasi, Tangerang: Graha Ilmu

Abraham_Silberschatz, Henry F., and Sudashan S. (2002). Database system concepts. Volume 1 Mcgraw-Hill Higher Education.

Budi Sutedjo Dharma Oetomo. 2006. Perancangan \& Pembangunan Sistem Informasi, Yogyakarta: ANDI

Hartono, Jogiyanto. 1999. Analisis Dan Sistem Informasi http://tonyjustinus.wordpress.com/2007/11/11/waterfallprocess-model/. Waterfall Process Model. Diakses 08 April 2013

Janner Simarmata \& Iman Paryudi. 2005. Basis Data, Yogyakarta: ANDI.

McLeod. 2004. Sistem Informasi. PT.Indeks.Jakarta

O’Brien, James. A (2005). Pengantar Sistem Informasi Perseptif Bisnis dan Manajerial. Salemba.

Stephens and Plew. 2000. Database Design, Sams Publishing. 46290 USA.

Tata Sutabri. 2012. Konsep Sistem Informasi, Jakarta: ANDI

Yakub. 2012. Pengantar Sistem Informasi, Yogyakarta: Graha Ilmu. 